\section{Study on potential Clostridium botulinum growth and toxin production in Parma ham}

\author{
Giuseppe Merialdi, ${ }^{1}$ Mattia Ramini, ${ }^{1}$ \\ Giovanni Parolari, ${ }^{2}$ Silvana Barbuti, ${ }^{2}$ \\ Maria Angela Frustoli, ${ }^{2}$ Roberta Taddei, ${ }^{1}$ \\ Stefano Pongolini, ${ }^{1}$ Paolo Ardigò, ${ }^{1}$ \\ Paolo Cozzolino ${ }^{3}$ \\ ${ }^{1}$ Institute for Experimental Veterinary \\ Medicine of Lombardy and Emilia \\ Romagna, Brescia; ${ }^{2}$ Experimental Unit for \\ Food Preserves Industry, Parma; \\ ${ }^{3}$ Department of Public Health, Parma \\ Local Health Unit, Parma, Italy
}

\section{Abstract}

The objective of this study was to investigate Clostridium botulinum growth and toxin production in the industrially manufactured Italian Parma ham. The study focuses on the Parma ham production phase identified as maximum risk to $C$. botulinum proliferation, i.e. the transition from cold phase (salting and resting) to a phase carried out at temperature between 15 and $23^{\circ} \mathrm{C}$ (drying). A preliminary in vitro test was carried out in order to verify the capability of $6 C$. botulinum strains (1 type A, 4 type $\mathrm{B}$, and 1 type $\mathrm{E}$ strains) to grow in conditions of temperature, $\mathrm{pH}$ and $\mathrm{NaCl}$ concentration comparable to those of the beginning stage of ham drying. Five $C$. botulinum strains grew at $20^{\circ} \mathrm{C}$ and $\mathrm{pH} 6$, four strains produced toxin when inoculated at a concentration equal to $10^{3} \mathrm{cfu} / \mathrm{mL}$ at $\mathrm{NaCl}$ concentration of $4 \%$, while when the inoculum concentration was $10 \mathrm{cfu} / \mathrm{mL}, \mathrm{NaCl}$ concentration of $3 \%$ resulted the toxin-genesis limiting factor. An experimental contamination with a mixture of the $5 C$. botulinum strains selected by the preliminary in vitro test was performed on 9 thighs inoculated at the end of the resting phase. The study was designed to evaluate the potential growth and toxin production in extremely favourable conditions for the bacterium. Type B proteolytic $C$. botulinum toxin was produced after 14 days of incubation at $20^{\circ} \mathrm{C}$ in 2 thighs characterised by high weight, low number of days of resting and anomalous physiochemical characteristics [one for very low $\mathrm{NaCl}$ concentration (1.59\%), the other for elevated $\mathrm{pH}$ (6.27) and both for high water activity values $(>0.970)]$. The results of this research confirm that the cold resting step is a critical phase in the production process of Parma ham for the investigated hazard. Based on the present study, the long resting phase adopted in the manufacturing of Parma ham is proven effective to prevent the growth of $C$. botulinum, an event which could not otherwise be excluded if the hams were processed under less stringent technological conditions.

\section{Introduction}

Clostridium botulinum is a Gram-positive, anaerobic, spore-forming bacterium that causes the neuro-paralytic illness in humans and animals known as botulism (Smith and Sugiyama, 1988). Foodborne botulism is a severe but rare disease resulting from consumption of preformed botulinum neurotoxin in food, with as little as $30 \mathrm{ng}$ of toxin sufficient to cause illness and even death (Lund and Peck, 2000). The source of food contamination is represented by $C$. botulinum spores, which are widespread in the environment and represent the form of resistance of the organism. Foods that are most frequently involved in episodes of botulism are home-preserved foods, especially canned-vegetables. In the past, a number of cases related to the consumption of canned fish and meat have been described, and among these, cured hams of domestic preparation have been sporadically identified as the cause of botulism (Piersante et al., 1995; Roblot et al., 1994; Troillet and Praz, 1995; Peck and Stringer, 2005). In countries as Italy and France, where home preparation of cured ham have been in widespread use, among the few cases associated with meat, the ones caused by cured ham constituted the main part (Piersante et al., 1995; Roblot et al., 1994).

Seven serologically distinct types of botulinum neurotoxin, designated types $\mathrm{A}$ to $\mathrm{G}$ have been described. Two main groups of $C$. botulinum are recognised as causing foodborne botulism. These are proteolytic and nonproteolytic $C$. botulinum. Proteolytic strains of C. botulinum produce type A, B, or F toxins, and generates spores of high heat resistance. These strains are mesophilic and grow optimally at $35-37^{\circ} \mathrm{C}$, but not below $10^{\circ} \mathrm{C}$ (Lynt $e t$ al., 1982). The growth-limiting $\mathrm{pH}$ is 4.3-4.5 (Smelt et al., 1982), and inhibitory $\mathrm{NaCl}$ concentration in brine is 10\% (Peck and Stringer, 2005; Lindstrom et al., 2006).

Non proteolytic strains of $C$. botulinum produce type B, E, or F, toxins. Spores are of moderate heat resistance, the strains are psychrotrophic, with an optimum growth temperature of $26-30^{\circ} \mathrm{C}$, but the bacteria can multiply and form neurotoxin at temperatures as low as $3{ }^{\circ} \mathrm{C}$ (Eklund et al., 1967a, 1967b; Graham et al., 1997). The growth-limiting $\mathrm{pH}$ is 5 (Segner et al., 1966), and the minimum growth $\mathrm{NaCl}$ concentration is 5\% (Peck and Stringer, 2005; Lindstrom and Korkeala, 2006).

The strains belonging to proteolytic and non proteolytic groups possess different types of
Correspondence: Giuseppe Merialdi, Institute for Experimental Veterinary Medicine of Lombardy and Emilia Romagna, via Pietro Fiorini 5, 40127 Bologna, Italy.

Tel: +39.051 .4200011 - Fax: +39.051 .4200038 .

E-mail: giuseppe.merialdi@izsler.it

Key words: Botulism; Dry cured ham; Toxinogenesis.

Funding: this work was supported by the Italian Ministry of Health (grant IZSLER PRC2010/017).

Received for publication: 5 0ctober 2015.

Revision received: 13 January 2016.

Accepted for publication: 25 January 2016.

This work is licensed under a Creative Commons Attribution-NonCommercial 4.0 International License (CC BY-NC 4.0).

CC Copyright G. Merialdi et al., 2016

Licensee PAGEPress, Italy

Italian Journal of Food Safety 2016; 5:5564

doi:10.4081/ijfs.2016.5564

risks in food processing. Proteolytic strains are frequently related to insufficiently processed home-preserved foods such as canned vegetables and cured meats. Non proteolytic strains, owing to their ability to grow at refrigerated temperatures, are a safety risk in modern industrially processed foods since these foods are processed with mild heat treatments that may allow the survival of non proteolytic $C$. botulinum spores (Lindstrom et al., 2006).

This research aims to investigate the potential growth and toxin production of $C$. botulinum in typical Italian Parma ham. In cured ham, the slight acidity of the meat together with the use of sodium chloride and nitrate as preservatives have traditionally resulted in a high safety level. In particular, nitrates are converted into nitrites, the primary use of which as antimicrobial compounds is the inhibition of $C$. botulinum growth and toxin production.

Parma-ham was selected as experimental model for this study since its production process, differently from most other Italian and Europeans hams, does only admit the use of sodium chloride as preservative and prohibits other chemical additives as nitrates and nitrites for $C$. botulinum control (Italian Republic 1993).

A variety of processing practices in dry cured ham production have been developed throughout centuries using different raw materials, ageing times and manufacturing techniques (Arnau, 1998; Toldrà et al., 1997; Virgili et al., 1997; Zlender and Cepin, 2003).

Parma ham is obtained from selected pig thighs, undergoing mild salting and a maturation period of at least 12 months. 
Typical Parma hams are processed in plants operating in accordance with mandatory regulations given by the Consortium (Parma Ham Consortium Regulation, 1992). The production process has not changed through the centuries, and is mainly based on the reduction of the water activity induced by sodium chloride diffusion within the thigh muscle and by the removal of moisture along with the drying process which takes place during ageing (Parolari, 1996). In agreement with the Parma Ham Consortium Regulation, the technology of Parma ham consists of two phases, a cold phase composed of the traditional stages of dry-salting for $2-4$ weeks at $0 \pm 5^{\circ} \mathrm{C}$, pre-resting for $1-2$ weeks at $0 \pm 5^{\circ} \mathrm{C}$ and resting at $1 \pm 6^{\circ} \mathrm{C}$ at least until the $80^{\text {th }}$ day from the beginning of processing (this duration may increase significantly, according to the initial weight of the leg, fat content and season and in any case until they reach an overall weight loss of $13 \%$ minimum from process start), followed by a phase of maturing and ageing (drying and curing) carried out at room temperature (Figure 1). During the resting phase the salt located on the surface and in the outer zones of the thigh penetrate the deeper zones, thus decreasing the water activity and ensuring ham preservation in the following steps (drying-maturing) carried out at room temperature. The research and experimental evidence indicate that an adequate lowering of the internal $\mathrm{a}_{\mathrm{w}}$ would not be obtained without a prolonged resting phase, except at the cost of a higher addition of salt, incompatible with the constraints of the production process.

The phase of maximum potential risk for botulinum toxin-genesis was identified in the transition from the last phase of the overall cold period (resting) to the first phase at higher temperature (drying) (Piersante et al., 1995). In fact, at this stage of production the following critical conditions are recognized: permissive temperature, salt content of the thighs still limited (2-3\%) and as a consequence, water content rather high. Two experimental studies were carried out: a preliminary in vitro study to investigate and substantiate the capability of $C$. botulinum to grow and produce toxin in conditions of $\mathrm{pH}, \mathrm{NaCl}$ concentration and temperature referable to that of the beginning of the drying phase followed by an experimental contamination of thighs collected late in the resting phase.

\section{Materials and Methods}

\section{Clostridium botulinum strains}

One type A strain (reference strain ATCC 19397), four type B strains (reference strains ATCC 17844, food isolates IZSLER 172977, IZSLER 11973 and IZSLER 92331) of proteolyt- ic $C$. botulinum and one type E strain (reference strain ATCC 17786) of non proteolytic $C$. botulinum were used in this study.

The strains were grown in Cooked Meat Medium (CMM) (Robertson, 1916) broth at $30^{\circ} \mathrm{C}$ for 15 days under anaerobic conditions using an anaerobic gas-generating kit (BioMerieux, Marcy l'Etoile, France). The spores were harvested and the supernatant has been discarded. In order to ensure the complete removal of the toxin, the sediment was washed twice in sterile saline water and re-suspended in the same medium. Each suspension was heat treated $\left(80^{\circ} \mathrm{C}\right.$ for $10 \mathrm{~min}$ for proteolytic strains and $60^{\circ} \mathrm{C}$ for 15 min for non proteolytic strain). The absence of the toxin was confirmed by an ELISA test performed on the suspension (Botulinum toxin A ELISA, Botulinum toxin B ELISA, Botulinum toxin E ELISA - Tetracore) carried out according to manufacturer instructions.

\section{Plate counts of Clostridium botulinum}

Decimal dilution of CMM broth were spread on Egg Yolk Agar (EYA) (Italian National Reference Centre for Botulism CNRB, 2015) and incubated under anaerobic conditions for $72 \mathrm{~h}$ at $37^{\circ} \mathrm{C}$. Lipase-positive colonies characteristic of $C$. botulinum were enumerated and confirmed by Gram staining.

\section{In vitro growth test}

For in vitro test Triptone Peptone Glucose Yeast extract (TPGY) broth (Italian National Reference Centre for Botulism CNRB, 2015) supplemented with $\mathrm{NaCl}$ at different concentrations was used. TPGY broths adding 1-2-3-4$5-6-7-8 \%(w / v) ~ N a C l$ were prepared and the $\mathrm{pH}$ of the media were adjusted to give a final value of 6.0 by the addition of $1 \mathrm{M} \mathrm{HCl}$.

Each $C$. botulinum strain was individually inoculated in two series of $10 \mathrm{ml}$ TPGY tubes with the different $\mathrm{NaCl}$ concentrations, one series of tubes being inoculated to a final concentration of $10 C$. botulinum spores $/ \mathrm{mL}$, the other to a final concentration of $10^{3} \mathrm{C}$. botulinum spores/mL.

The tubes were incubated at $20^{\circ} \mathrm{C}$ under anaerobic conditions and examined after 7 and 28 days of incubation. An appreciable turbidity of the broth, followed by Gram staining positive for Gram positive spore-forming bacilli was considered indicative of spore germination. The suspension was then tested for the presence of the toxin by ELISA test (Botulinum toxin A ELISA, Botulinum toxin B ELISA, Botulinum toxin E ELISA - Tetracore) following manufacturer instructions.

\section{Experimental contamination}

Nine thighs were collected late in the resting phase and included in the study. Five different ham manufacturers were selected in order to take into account the product variabil- ity due to different production processes. In particular, variabilities in terms of duration of cold phase and in $\mathrm{NaCl}$ concentration were included. In order to investigate extreme or even abnormal conditions in a sort of worstcase scenario, the thighs were collected before the end of the resting phase, when a minimum weight loss of 13 should be warranted. Eight thighs were processed according to Parma Ham Consortium Tutelary Regulation (1992), while one thigh (N. 7) was produced by replacing $30 \%$ of $\mathrm{NaCl}$ with $\mathrm{KCl}$ (Table 1).

From each thigh, 1 sample of muscle tissue was aseptically removed from three different areas namely butt, core and shank, so to ensure values of water activity $\left(\mathrm{a}_{\mathrm{w}}\right), \mathrm{pH}$ and $\mathrm{NaCl}$ representative of the entire variability existing inside the thigh. Each sample was then divided in 5 cubes of $30 \mathrm{~g}$ weight (approximately $3 \times 3 \times 3 \mathrm{~cm}$ ) to constitute 5 equivalent set of samples from each sampling point.

\section{Preparation of inoculum}

The inoculum of $C$. botulinum spores consisted of approximately equal number of the five strains which showed growth and toxinogenesis in the in vitro test ( $C$. botulinum type A ATCC 19397, C. botulinum type B ATCC 17844, C. botulinum type E ATCC 17786 , food isolate $C$. botulinum type B IZSLER 172977, food isolate $C$. botulinum type B IZSLER 11793). Spore crops of each strain were prepared separately as described previously, heatshocked, enumerated as previously described, mixed and diluted in order to obtain an inoculum with an approximate final concentration of $2 \times 10^{3} \mathrm{cfu} / \mathrm{mL}$.

\section{Samples inoculation}

Four sets of samples were inoculated by deep syringing $50 \mu \mathrm{L}$ of the inoculum. Immediately after inoculum, one set was homogenized in Buffered Peptone Water and enumerated as previously described for the exact number of $C$. botulinum spores injected. Positive process control samples were arranged by inoculating 9 cubes of $30 \mathrm{~g}$ weight of fresh pork leg muscle. Inoculated samples and positive process control samples were vacuum packaged in bags of plastic material in order to reproduce the optimal $C$. botulinum growth conditions.

\section{Clostridium botulinum spore ger- mination and toxin production}

Based on the results of preliminary in vitro test, three set of samples were incubated at $20^{\circ} \mathrm{C}$ for 21 days. $C$. botulinum spore germination and toxin production were checked at 7 , 14 and 21 days post-contamination. For each incubation time point, 3 positive process control samples were included. At the end of the above mentioned incubation periods, thigh samples and process control samples were 
entirely homogenized in Buffered Peptone Water (1:2 dilution) and examined for $C$. botulinum spore germination by plating decimal dilution of sample homogenate on EYA agar. The incubation conditions and the confirmatory tests carried out on colonies referable to $C$. botulinum were performed as previously described. Sample homogenates were tested for the presence of the toxin by ELISA (Botulinum toxin A ELISA, Botulinum toxin B ELISA, Botulinum toxin E ELISA - Tetracore) following manufacturer instructions. The samples resulted positive for an increase in logarithmic $C$. botulinum concentration were typed by Real Time PCR specific for toxin A, B, E and F genes (Italian National Reference Centre for Botulism CNRB, 2015).

\section{Water activity, $\mathrm{pH}$ and $\mathrm{NaCl}$ deter- mination}

$\mathrm{pH}, \mathrm{a}_{\mathrm{w}}$ and $\mathrm{NaCl}$ concentration were determined on 1 set of not inoculated samples (1 sample from each of the three sampling points of the 9 thighs). Water activity was measured with the $\mathrm{a}_{\mathrm{w}}$ recorder AcquaLab, series 3 , Model TE (Decagon Devices, Inc., Pullman, USA), in accordance with ISO/FDIS 21807 (ISO, 2004). The $\mathrm{pH}$ was determined directly on samples with a Hamilton glass electrode probe attached to a portable pH-meter (WTW pH 330, Wilheim, Germany). The $\mathrm{NaCl}$ content was analysed according to AOAC method (AOAC, 2002).

\section{Results}

\section{In vitro growth test}

Table 2 shows the results of the in vitro assay. All the tested strains, apart from strain IZSLER 92331, showed bacterial multiplication in experimented conditions, regardless of the initial concentration of the inoculum. Nevertheless, at high $\mathrm{NaCl}$ concentrations the initial titre of the inoculum resulted a limiting factor for $C$. botulinum growth and toxin production. In fact, 4 of the 6 tested strains produced toxin after 28 days when inoculated at a concentration equal to $10^{3} \mathrm{cfu} / \mathrm{mL}$ at $\mathrm{NaCl}$ concentration of $4 \%$, while $\mathrm{NaCl}$ concentration of $3 \%$ resulted the limiting factor when the inoculum concentration was $10 \mathrm{cfu} / \mathrm{mL}$.

\section{Experimental contamination}

All positive control samples of fresh meat gave rise, after 7 days of incubation, to $C$. botulinum counts greater than $10^{6} \mathrm{cfu} / \mathrm{g}$ and test- ed positive for the presence of botulinum toxin type B by ELISA test. Table 3 shows in detail the results of the $C$. botulinum growth in the experimental contamination study. 24 of the 27 tested cubes have not given rise neither to $C$. botulinum growth, nor to the production of botulinum toxin. The production of botulinum toxin and $C$. botulinum growth occur exclusively in the shank of two thighs (2 and 9). After 7 days of incubation the toxin was never detected and only in the shank of the thighs 2 and 9 has been shown an increase of 1.97 and 2.55 logarithms of $C$. botulinum, respectively. In both cases the toxin production occurred after 14 days of incubation.

In both cases the strain which gave rise to the toxin production was a type B strain, as confirmed by ELISA test identifying type B toxin and Real Time PCR resulting positive for type B toxin gene presence.

In the core of sample 2 a significant increase in the concentration of $C$. botulinum was evidenced 14 days post contamination, but the toxin genesis was not demonstrated neither after 14 nor after 21 days post contamination.

Table 1. Characteristics of the thighs included in the study.

\begin{tabular}{lllll}
\hline Thigh no. & Manufacturer & Days from salting & Weight $(\mathrm{kg})$ & Effective duration of cold phase of the batch \\
1 & A & 101 & 11.2 & 116 \\
2 & B & 102 & 13.2 & 113 \\
\hline 3 & C & 108 & 10.7 & 117 \\
4 & D & 115 & 10.4 & 119 \\
\hline 5 & E & 119 & 12.7 & 127 \\
6 & A & 103 & 11.3 & 109 \\
\hline $7 *$ & A & 111 & 10.0 & 110 \\
8 & C & 96 & 12.5 & 101 \\
\hline 9 & E & 104 & 13.0 & 126 \\
\hline
\end{tabular}

*In the production protocol of this ham 30\% of NaCl has been replaced by KCl.

Table 2. Combined effect of $\mathrm{NaCl}$ and inoculum concentrations on growth and toxin production of six Clostridium botulinum strains.

\begin{tabular}{|c|c|c|c|c|c|c|c|c|c|c|c|c|c|c|c|c|c|c|}
\hline $\begin{array}{r}\text { In } \\
\text { con } \\
(\end{array}$ & $\begin{array}{l}\text { oculum } \\
\text { entration } \\
\text { fu/mL) }\end{array}$ & $\mathrm{NaCL}(\%)$ & 1 & 2 & 3 & $\begin{array}{l}7 \\
4\end{array}$ & 5 & ubs & on & 8 & 1 & 2 & $3^{28}$ & 4 & 5 & 6 & 7 & 8 \\
\hline ATCC 19397 & $\begin{array}{c}10 \\
10^{3}\end{array}$ & $\begin{array}{l}3 \\
4\end{array}$ & $\begin{array}{l}\mathrm{G}+\mathrm{TP} \\
\mathrm{G}+\mathrm{TP}\end{array}$ & $\begin{array}{l}\mathrm{G}+\mathrm{TP} \\
\mathrm{G}+\mathrm{TP}\end{array}$ & I & $\begin{array}{l}1 \\
1\end{array}$ & 1 & 1 & $\begin{array}{l}1 \\
1\end{array}$ & $\begin{array}{l}1 \\
1\end{array}$ & $\begin{array}{l}\mathrm{G}+\mathrm{TP} \\
\mathrm{G}+\mathrm{TP}\end{array}$ & $\begin{array}{l}\mathrm{G}+\mathrm{TP} \\
\mathrm{G}+\mathrm{TP}\end{array}$ & $\begin{array}{c}/ \\
\text { G+TP }\end{array}$ & $\begin{array}{c}/ \\
\mathrm{G}+\mathrm{TP}\end{array}$ & $\begin{array}{l}1 \\
1\end{array}$ & $\begin{array}{l}1 \\
1\end{array}$ & 1 & I \\
\hline ATCC 17786 & $\begin{array}{c}10 \\
10^{3} \\
\end{array}$ & $\begin{array}{l}3 \\
4 \\
\end{array}$ & $\begin{array}{l}\text { G+TP } \\
\text { G+TP }\end{array}$ & $\begin{array}{l}\mathrm{G}+\mathrm{TP} \\
\mathrm{G}+\mathrm{TP}\end{array}$ & $\begin{array}{c}\mathrm{G} \\
\mathrm{G}+\mathrm{TP}\end{array}$ & $\begin{array}{l}1 \\
1\end{array}$ & 1 & $\begin{array}{l}1 \\
1\end{array}$ & $\begin{array}{l}1 \\
1\end{array}$ & $\begin{array}{l}1 \\
1\end{array}$ & $\begin{array}{l}\mathrm{G}+\mathrm{TP} \\
\mathrm{G}+\mathrm{TP}\end{array}$ & $\begin{array}{l}\text { G+TP } \\
\text { G+TP }\end{array}$ & $\begin{array}{l}\mathrm{G}+\mathrm{TP} \\
\mathrm{G}+\mathrm{TP}\end{array}$ & $\begin{array}{c}\text { / } \\
\text { G+TP }\end{array}$ & $\begin{array}{l}1 \\
1\end{array}$ & $\begin{array}{l}1 \\
1\end{array}$ & $\begin{array}{l}1 \\
1\end{array}$ & 1 \\
\hline ATCC 17844 & $\begin{array}{c}10 \\
10^{3}\end{array}$ & $\begin{array}{l}3 \\
4\end{array}$ & $\begin{array}{l}\mathrm{G}+\mathrm{TP} \\
\mathrm{G}+\mathrm{TP}\end{array}$ & $\begin{array}{l}\mathrm{G}+\mathrm{TP} \\
\mathrm{G}+\mathrm{TP}\end{array}$ & I & $\begin{array}{l}1 \\
1\end{array}$ & $\begin{array}{l}1 \\
1\end{array}$ & $\begin{array}{l}1 \\
1\end{array}$ & I & $\begin{array}{l}1 \\
1\end{array}$ & $\begin{array}{l}\mathrm{G}+\mathrm{TP} \\
\mathrm{G}+\mathrm{TP}\end{array}$ & $\begin{array}{l}\mathrm{G}+\mathrm{TP} \\
\mathrm{G}+\mathrm{TP}\end{array}$ & $\begin{array}{l}\text { G+TP } \\
\text { G+TP }\end{array}$ & $\begin{array}{c}/ \\
\mathrm{G}+\mathrm{TP}\end{array}$ & $\begin{array}{l}1 \\
1\end{array}$ & $\begin{array}{l}1 \\
1\end{array}$ & $\begin{array}{l}1 \\
1\end{array}$ & i \\
\hline 92331 IZSLER & $\begin{array}{c}10 \\
10^{3}\end{array}$ & $\begin{array}{l}3 \\
4\end{array}$ & I & 1 & I & $\begin{array}{l}1 \\
1\end{array}$ & $\begin{array}{l}1 \\
1\end{array}$ & $\begin{array}{l}1 \\
1\end{array}$ & $\begin{array}{l}1 \\
1\end{array}$ & $\begin{array}{l}1 \\
1\end{array}$ & 1 & $\begin{array}{l}1 \\
1\end{array}$ & I & 1 & $\begin{array}{l}1 \\
1\end{array}$ & $\begin{array}{l}1 \\
1\end{array}$ & $\begin{array}{l}1 \\
1\end{array}$ & I \\
\hline 172977 IZSLER & $\begin{array}{c}10 \\
10^{3}\end{array}$ & $\begin{array}{l}3 \\
4\end{array}$ & $\begin{array}{l}\mathrm{G}+\mathrm{TP} \\
\mathrm{G}+\mathrm{TP}\end{array}$ & $\begin{array}{l}\mathrm{G}+\mathrm{TP} \\
\mathrm{G}+\mathrm{TP}\end{array}$ & $\begin{array}{l}\mathrm{G} \\
\mathrm{G}\end{array}$ & $\begin{array}{l}1 \\
1\end{array}$ & $\begin{array}{l}1 \\
1\end{array}$ & $\begin{array}{l}1 \\
1\end{array}$ & I & $\begin{array}{l}1 \\
1\end{array}$ & $\begin{array}{l}\mathrm{G}+\mathrm{TP} \\
\mathrm{G}+\mathrm{TP}\end{array}$ & $\begin{array}{l}\mathrm{G}+\mathrm{TP} \\
\mathrm{G}+\mathrm{TP}\end{array}$ & $\begin{array}{l}\text { G+TP } \\
\text { G+TP }\end{array}$ & $\begin{array}{c}\mathrm{G} \\
\mathrm{G}+\mathrm{TP}\end{array}$ & $\begin{array}{l}1 \\
1\end{array}$ & $\begin{array}{l}1 \\
1\end{array}$ & $\begin{array}{l}1 \\
1\end{array}$ & I \\
\hline 11793 IZSLER & $\begin{array}{c}10 \\
10^{3} \\
\end{array}$ & $\begin{array}{l}3 \\
4 \\
\end{array}$ & $\begin{array}{l}\text { G+TP } \\
\text { G+TP }\end{array}$ & $\begin{array}{l}\mathrm{G}+\mathrm{TP} \\
\mathrm{G}+\mathrm{TP}\end{array}$ & $\begin{array}{l}\mathrm{G} \\
\mathrm{G}\end{array}$ & $\begin{array}{l}1 \\
1\end{array}$ & $\begin{array}{l}1 \\
1\end{array}$ & 1 & $\begin{array}{l}1 \\
1\end{array}$ & $\begin{array}{l}1 \\
1\end{array}$ & $\begin{array}{l}\mathrm{G}+\mathrm{TP} \\
\mathrm{G}+\mathrm{TP}\end{array}$ & $\begin{array}{l}\text { G+TP } \\
\text { G+TP }\end{array}$ & $\begin{array}{l}\mathrm{G}+\mathrm{TP} \\
\mathrm{G}+\mathrm{TP}\end{array}$ & 1 & $\begin{array}{l}1 \\
1\end{array}$ & $\begin{array}{l}1 \\
1\end{array}$ & $\begin{array}{l}1 \\
1\end{array}$ & $\begin{array}{l}1 \\
1\end{array}$ \\
\hline
\end{tabular}

G, growth; TP, toxin production. 


\section{Discussion}

Even though among the few Italian cases of botulism associated with meat, the ones linked to home prepared cured-ham constitutes the main part (Piersante et al., 1995), industrially produced cured-hams have never been associated with episodes of botulism. In particular, no epidemiological evidence links the consumption of Parma ham to risk of botulism or other foodborne illness, in spite of the prohibition of using additives and preservatives as nitrites and nitrates in its production process.

This study investigates the phase identified at maximum potential risk to $C$. botulinum proliferation i.e. the transition from resting phase to drying phase (Piersante et al., 1995).

In particular, after having confirmed by the in vitro test that $C$. botulinum would have been able to grow and produce toxin under conditions of temperature, $\mathrm{pH}$ and $\mathrm{NaCl}$ concentration comparable to those of the beginning stage of ham drying, an experimental contamination has been carried out on thighs at this stage of production.

Data on chemical and physical parameters of thighs subjected to the experimental contamination confirmed that $\mathrm{pH}, \mathrm{a}_{\mathrm{w}}$ and $\mathrm{NaCl}$ concentration are critical factors. In particular, water reduction as obtained by combined salt diffusion and dehydration, is the primary limiting factor for the growth of $C$. botulinum, as shown by the absence of growth in all samples with $\mathrm{a}_{\mathrm{w}}<0.97$. Conversely, if salt contents were abnormally low, hence their $\mathrm{a}_{\mathrm{w}}$ not adequately decreased, the pathogen might eventually grow, as demonstrated by the purposely selected low-salt samples with $a_{w}>0.97$. In this case, an appropriate extension of the cold resting phase would help to achieve an additional moisture loss, warranting the necessary decrease in water activity to below the threshold $\mathrm{a}_{\mathrm{w}}$ value of 0.97 .

In the current practice, the achievement of a weight loss of $13 \%$ at the end of the cold stage (resting phase) results in $\mathrm{a}_{\mathrm{w}}$ decrease to less than 0.97 , warranting the prevention of growth of any $C$. botulinum spores that would have survived.

The experimental contamination study revealed that $C$. botulinum multiplication occurred in 2 out of the 9 tested thighs, in particular the bacteria was grown both in the shank and in the core of thigh 9 and in the shank of thigh 2 (Figure 2). The toxin was produced in the shanks of both thighs. The strain which gave rise to multiplication and toxin production was in both cases a type B proteolytic strain. It is worth noting that its development was always accompanied by evident organoleptic alterations as texture softening and development of unpleasant smell. Type B C. botulinum strain or type B neurotoxin were also the ones detected in suspected food or patients' serum samples from other reported episodes of botulism associated with curedham (Piersante et al., 1995; Roblot et al., 1994). The only non-proteolytic strain used in the study did not result in multiplication and toxin production. It is well known that the nonproteolytic strains exhibit reduced resistance to $\mathrm{NaCl}$ compared to proteolytic ones, while being characterised by higher adaptation to low temperatures (Eklund et al., 1967a, 1967b; Graham et al., 1997; Peck and Stringer, 2005; Lindstrom and Korkeala, 2006).

The two thighs (identified as 2 and 9) were both characterised by high weight and low number of days of resting, both factors having presumably affected the overall penetration of the salt in the muscles. In both cases toxin production was reported in the sampled portion where salt concentration is typically the lowest of the thigh, namely shank. Thigh 2 presents salt concentration lower than all the other tested thighs: $\mathrm{NaCl}$ concentration in the shank

Table 3. Results of Clostridium botulinum growth in thighs after experimental contamination.

\begin{tabular}{|c|c|c|c|c|c|c|c|c|}
\hline \multirow[t]{2}{*}{$\begin{array}{l}\text { Thigh } \\
\text { no. }\end{array}$} & \multirow[t]{2}{*}{$\begin{array}{l}\text { Sampling } \\
\text { point }\end{array}$} & \multirow[t]{2}{*}{$a_{w}$} & \multirow[t]{2}{*}{$\mathrm{pH}$} & \multirow[t]{2}{*}{$\begin{array}{l}\mathrm{NaCl} \\
(\%)\end{array}$} & \multirow{2}{*}{$\begin{array}{l}\text { Initial } C \text {. botulinum } \\
\text { contamination } \\
\left(\log \mathrm{cfu} \mathrm{g}^{-1}\right)\end{array}$} & \multicolumn{3}{|c|}{$\begin{array}{l}\text { C. botulinum enumeration } \\
\left(\operatorname{Log~cfu~g~}^{-1}\right)\end{array}$} \\
\hline & & & & & & $7 \mathrm{dpc}$ & $14 \mathrm{dpc}$ & $21 \mathrm{dpc}$ \\
\hline \multirow[t]{3}{*}{1} & Shank & 0.959 & 5.98 & 3.35 & 0.79 & 1.00 & 0.70 & 0.70 \\
\hline & Core & 0.955 & 5.97 & 3.74 & 0.79 & 0.70 & 0.70 & 0.70 \\
\hline & Butt & 0.943 & 5.96 & 4.89 & 0.79 & 1.00 & 0.70 & 0.402 \\
\hline \multirow[t]{3}{*}{2} & Shank & 0.975 & 5.78 & 1.59 & 0.79 & 2.76 & 5.35 & 5.35 \\
\hline & Core & 0.973 & 5.79 & 2.00 & 0.79 & 1.00 & 4.62 & 4.60 \\
\hline & Butt & 0.957 & 6.17 & 3.45 & 0.79 & 0.70 & 1.00 & 1.00 \\
\hline \multirow[t]{3}{*}{3} & Shank & 0.966 & 5.78 & 2.61 & 0.85 & 1.00 & 1.15 & 0.78 \\
\hline & Core & 0.969 & 5.73 & 2.62 & 0.85 & 0.85 & 1.00 & 1.18 \\
\hline & Butt & 0.954 & 5.80 & 5.73 & 0.85 & 1.00 & 0.70 & 1.18 \\
\hline \multirow[t]{3}{*}{4} & Shank & 0.962 & 5.85 & 3.17 & 0.85 & 1.00 & 0.70 & 0.70 \\
\hline & Core & 0.967 & 5.69 & 3.02 & 0.85 & 1.08 & 1.04 & 0.70 \\
\hline & Butt & 0.912 & 5.67 & 7.25 & 0.85 & 0.70 & 0.70 & 1.00 \\
\hline \multirow[t]{3}{*}{5} & Shank & 0.972 & 5.73 & 2.51 & 0.80 & 1.00 & 1.00 & 1.00 \\
\hline & Core & 0.973 & 5.89 & 2.26 & 0.80 & 0.85 & 1.15 & 0.70 \\
\hline & Butt & 0.943 & 6.11 & 5.24 & 0.80 & 0.85 & 1.30 & 1.00 \\
\hline \multirow[t]{3}{*}{6} & Shank & 0.966 & 6.09 & 3.32 & 1.01 & 1.30 & 1.23 & 1.18 \\
\hline & Core & 0.968 & 5.78 & 4.44 & 1.01 & 1.00 & 1.00 & 1.18 \\
\hline & Butt & 0.967 & 5.90 & 4.75 & 1.01 & 1.30 & 1.40 & 1.30 \\
\hline \multirow[t]{3}{*}{7} & Shank & 0.967 & 5.80 & 2.78 & 1.01 & 1.40 & 1.00 & 1.00 \\
\hline & Core & 0.954 & 5.88 & 3.19 & 1.01 & 1.30 & 1.30 & 1.20 \\
\hline & Butt & 0.954 & 5.82 & 5.11 & 1.01 & 1.30 & 1.30 & 1.00 \\
\hline \multirow[t]{3}{*}{8} & Shank & 0.964 & 5.70 & 2.26 & 0.75 & 1.00 & 0.70 & 0.70 \\
\hline & Core & 0.964 & 5.58 & 2.35 & 0.75 & 1.00 & 1.00 & 0.70 \\
\hline & Butt & 0.955 & 5.85 & 3.73 & 0.75 & 1.00 & 1.30 & 1.30 \\
\hline \multirow[t]{3}{*}{9} & Shank & 0.970 & 6.27 & 2.48 & 0.75 & 3.30 & 5.02 & 5.40 \\
\hline & Core & 0.966 & 5.72 & 2.82 & 0.75 & 1.00 & 1.00 & 0.70 \\
\hline & Butt & 0.949 & 5.86 & 4.69 & 0.75 & 0.70 & 0.70 & 0.70 \\
\hline
\end{tabular}

C. botulinum, Clostridium botulinum; dpc, days post contamination. 
resulted remarkably low (1.59\%) and the data in the core where $C$. botulinum proliferation without toxin production was recorded, is slightly higher (2\%). On the contrary, the shank of the thigh 9 showed NaCl concentration comparable to those of other thighs in which there was no evident multiplication of C. botulinum, but in this sample the $\mathrm{pH}$ was very high (6.27) when compared to other thighs composing the studied set. Additionally the $\mathrm{a}_{\mathrm{w}}$ values of the three samples where $C$. botulinum multiplication was detected were equal or greater than 0.97 while the $a_{w}$ value regarded as a safety threshold in traditional Parma dry-cured hams at the end of resting phase is considered 0.96 (Schivazappa et al., 2013). Our results show that $C$. botulinum growth and the toxin production have occurred exclusively in two samples of atypical thigh with anomalous physiochemical characteristic, one for very low $\mathrm{NaCl}$ concentration

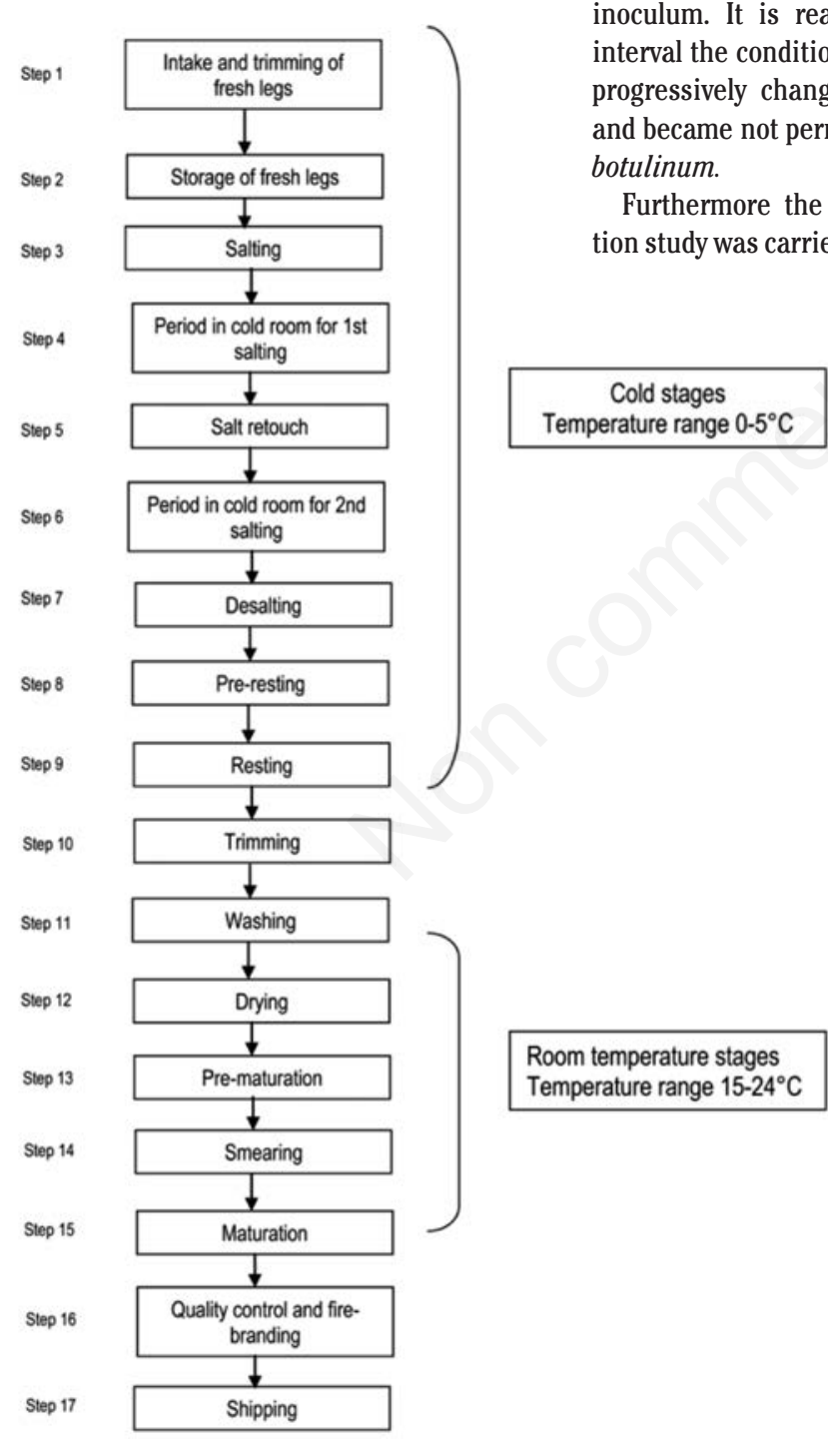

Figure 1. Schematic diagram showing the production process of Parma ham.
(1.59\%), the other for high $\mathrm{pH}$ (6.27) and both for $a_{w}$ values above the safety Parma-ham set threshold (Figure 2). This result, apparently in contrast with the epidemiological data referring no link between Parma ham and botulism, should be evaluated considering the following point. In regards to the experimental contamination, some specifications on the experimental model used are needed to correctly interpret the data reported.

The cubes used for the experimental contamination were extracted from the thighs late in the resting period. In thighs during the drying phase a salt migration occurs from the outer portions to the internal ones due to the osmotic effect, consequently during this phase the salt concentration is dynamic and progressively increasing in time. This effect could not have been included in the study since the cubes were excised from the surrounding muscles. In the experimental contamination, toxin production was observed at day 15 after the inoculum. It is reasonable that during this interval the conditions of the tight would have progressively changed due to salt migration and became not permissive to the growth of $C$. otulinum.

Furthermore the experimental contaminaon study was carried out at $20^{\circ} \mathrm{C}$, whereas the factual condition of Parma ham production process is such that during the drying phase the average temperature of the thighs reaches a maximum temperature of $19^{\circ} \mathrm{C}$ to stabilise within 72 hours at around $18^{\circ} \mathrm{C}$.

The inoculum was performed deeply in the ham cube with a punctiform inoculation of 50 $\mathrm{l}$ of a solution containing $2 \mathrm{X} 10^{3} \mathrm{cfu} / \mathrm{mL}$ which is a more challenging scenario in respect of what can be expected in field conditions.

Therefore the experimental model, deliberately designed as a worst-case scenario, resulted more favorable to the multiplication of the bacterium than what normally occurs in ham production process, and the results should be evaluated in this regard.

On the one hand, the experimental condition adopted in this study account for the safety of the Parma ham production procedures in relation to $C$. botulinum multiplication, as the tested thighs showing typical physiochemical characteristics did not support any growth. On the other hand, the results of this research, confirm that the drying step is a critical phase in the production process of the Parma ham for the investigated hazard as our experimental model shows that in case of permissive incubation temperature and atypical physiochemical characteristic of the thighs, the occurrence
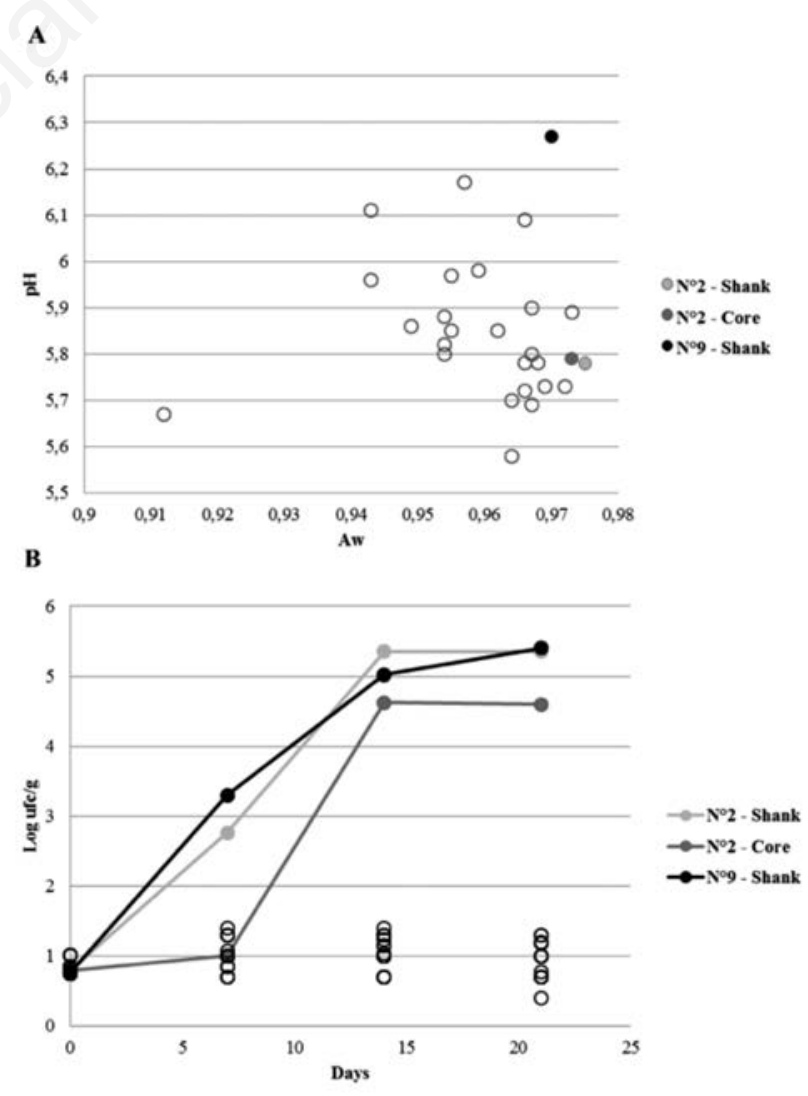

Figure 2. Clostridium botulinum multiplication (A) and physiochemical characteristics (B) of the tested thighs. Empty circles represent samples where Clostridium botulinum multiplication did not occur. 
of $C$. botulinum multiplication and toxin-genesis cannot be completely excluded.

In this context, we should notice that the search by ham producers of extreme conditions required by the market, for example the excessive softness and tenderness of the product, can lead to particularly hazardous conditions. The evidence that an excessive sodium intake is one of the main factors for the development of hypertension and cardiovascular disease (WHO, 2003) together with the indication of the World Cancer Research Fund of salt, as well as salted and salty foods, being a probable cause of stomach cancer (World Cancer Research Fund, 2007), has induced an increasing demand on the part of the consumers for a decrease in salt content in food. Recent studies on the effects of salt reduction on Parma production process (Benedini et al., 2012; Schivazappa et al., 2013) conclude that manufacturers aiming to decrease salt without adversely affecting ham qualities could extend maturing time while preventing abnormal proteolysis, by checking raw legs for their enzyme activities and keeping the process under strict environmental control.

The reduction of salt content in dry-cured ham by either lowering the addition of sodium chloride (Andrés et al., 2004) or by partially replacing sodium chloride by other chloride salts (Armenteros et al., 2012; Armenteros and Aristoy, 2012) have also been investigated, but at present the application of these new technologies is supported by a still limited scientific literature.

\section{Conclusions}

In conclusion, the reported data appear to be a useful tool for ham manufacturers in order to more clearly identify and plan verification procedures for controlling the risk of $C$. botulinum proliferation during Parma ham production. In particular, the duration of the resting phase, the accurate temperature monitoring during the drying phase and the strict control of physio chemical characteristics of the thighs entering this stage of production resulted the most critical points.

\section{References}

Andrés AI, Cava R, Ventanas J, Muriel E, Ruíz J, 2004. Lipid oxidative changes throughout the ripening of dry-cured hams with different salt contents and processing conditions. Food Chem 84:375-81.

AOAC, 2002. Official methods of analysis. 17th ed. Association of Analytical Chemists, Arlington,
VA, USA

Armenteros M, Aristoy MC, Barat JM, Toldrá F, 2012. Biochemical and sensory changes in drycured ham salted with partial replacements of $\mathrm{NaCl}$ by other chloride salts. Meat Sci 90:361-7.

Armenteros M, Aristoy MC, 2012. Evolution of nitrate and nitrite during the processing of drycured ham with partial replacement of $\mathrm{NaCl}$ by other chloride salts. Meat Sci 91:378-81.

Arnau J, 1998. Tecnología de fabricación del jamón curado en distintos países. Available from: www.eurocarne.com/daal?al=informes\&a2=JamonCurado.pdf

Benedini R, Parolari G, Toscani T, Virgili R, 2012. Sensory and texture properties of Italian typical dry-cured hams as related to maturation time and salt content. Meat Sci 90:431-7.

Eklund MW, Poysky FT, Wieler DI, 1967a. Characteristics of Clostridium botulinum type F isolated from the Pacific Coast of the United States. Appl Microbiol 15:1316-23.

Eklund MW, Wieler DI, Poysky FT, 1967b. Outgrowth and toxin production of non-proteolytic type B Clostridium botulinum at 3.3 to 5.6 -C. J Bacteriol 93:1461-2.

Graham AF, Mason DR, Maxwell FJ, Peck MW, 1997. Effect of $\mathrm{pH}$ and $\mathrm{NaCl}$ on growth from spores of nonproteolytic Clostridium botulinum at chill temperature. Lett Appl Microbiol 24:95-100.

Italian National Reference Centre for Botulism CNRB, 2015. Method CNRB31.000. Available from: http://www.iss.it/binary /spva4/cont/ CNRB30.000.pdf

ISO, 2004. Microbiology of food and animal feeding stuffs. Determination of water activity. ISO Norm ISO/FDIS 21807:2004. International Organization for Standardization, Geneva, Switzerland.

Italian Republic, 1993. Ministry Decree 253 of 15 February 1993. In: Official Journal, L 173, 26/07/1993.

Lindström M, Kiviniemi K, Korkeala H, 2006. Hazard and control of group II (non-proteolytic) Clostridium botulinum in modern food processing. Int J Food Microbiol 108:92-104.

Lindstrom M, Korkeala H, 2006. Laboratory diagnostics of botulism. Clin Microbiol Rev 19:298314.

Lund BM, Peck MW, 2000. Clostridium botulinum. In: Lund BM, Baird-Parker AC, Gould GW, eds. The microbiological safety and quality of food. Aspen, Gaithersburg, ML, USA, pp 1057-109.

Lynt RK, Kautter DA, Solomon HM, 1982. Differences and similarities among proteolytic and nonproteolytic strains of Clostridium botulinum types A, B, E, and F: a review. J Food Protect 45:466-74.

Parma Ham Consortium Regulation, 1992. POD, product origin designation. Disciplinare generale e dossier, articolo 4 del Regolamento CEE No. 2081/92 del Consiglio del 14 luglio 1992. Consorzio del Prosciutto di Parma, Parma,
Italy.

Parolari G, 1996. Achievements, needs and perspectives in dry-cured ham technology: the example of Parma-ham. Food Sci Technol Int 2:69-78.

Peck MW, Stringer SC, 2005. The safety of pasteurised in-pack chilled meat products with respect to the foodborne botulism hazard. Meat Sci 70:461-75.

Piersante GP, Marino A, Fenicia L, Moro ML, Aureli P, 1995. A large outbreak of botulism caused by home cured ham consumption. Ann Ig 7:451-8.

Robertson M, 1916. Notes upon certain anaerobes isolated from wounds. $\mathrm{J}$ Pathol Bacteriol 20:327-49.

Roblot P, Roblot F, Fauchère JL, Devilleger A, Maréchaud R, Breux JP, Grollier G, BecqGiraudon B, 1994. Retrospective study of 108 cases of botulism in Poitiers, France. J Med Microbiol 40:379-84.

Schivazappa C, Pinna A, Virgili R, 2013. Effect of salt reduction on the length of the resting stage of Italian typical dry cured ham. Acta Agr Slov 4:189-92.

Segner WP, Schmidt CF, Boltz JK, 1966. Effect of sodium chloride and $\mathrm{pH}$ on the outgrowth of spores of type E Clostridium botulinum at optimal and suboptimal temperatures. Appl Microbiol 14:49-54.

Smelt JP, Raatjes GJ, Crowther JS, Verrips CT, 1982. Growth and toxin formation by Clostridium botulinum at low $\mathrm{pH}$ values. J Appl Bacteriol 52:75-82.

Smith LDS, Sugiyama H, 1988. Botulism. The organism, its toxins, the disease, 2nd ed. Charles C Thomas, Springfield, IL, USA.

Toldrà F, Flores M, Navarro JL, Aristoy MC, Flores $\mathrm{J}$, 1997. New developments in dry-cured ham. In: Okai H, Mills 0, Spanier AM, Tamura M, eds. Chemistry of novel foods. Carol Stream, IL, USA: Allured Pub. Co, pp 259-272.

Troillet N, Praz G, 1995. Epidemic of type B botulism: Sion, December 1993-January 1994. Schweiz Med Wschr 125:1805-12.

Virgili R, Parolari G, Soresi Bordini C, Schivazappa C, 1997. Sensory and analytical investigations into six types of European hams: Parma, Serrano, Bayonne, Italian country-style, Iberian and Corsican. Industria Conserve 72:134-43.

WHO, 2003. Diet, nutrition and the prevention of chronic diseases. World Health Organization, Geneva, Switzerland.

World Cancer Research Fund, 2007. Food, nutrition, physical activity, and the prevention of cancer: a global perspective. American Institute for Cancer Research, Washington, DC, USA.

Zlender B, Cepin S, 2003. Traditional Slovenian meat products. Fleischwirtschaft 83:81-5. 